\title{
Genetic diversity of Hirsutella thompsonii isolates from Thailand based on AFLP analysis and partial $\beta$-tubulin gene sequences
}

\author{
Myrian S. Tigano ${ }^{1}$, Byron Adams ${ }^{2}$, Saowanit Maimala ${ }^{3}$ and Drion Boucias ${ }^{4}$ \\ ${ }^{1}$ Embrapa Recursos Genéticos e Biotecnologia, Parque Estação Biológica, Final, Brasília, DF, Brazil. \\ ${ }^{2}$ Department of Microbiology \& Molecular Biology, Brigham Young University, Provo, UT, USA. \\ ${ }^{3}$ Department of Entomology, Kasetsart University, Bangkok, Thailand. \\ ${ }^{4}$ Department of Entomology and Nematology, University of Florida, Gainesville, FL, USA.
}

\begin{abstract}
Amplified fragment length polymorphism (AFLP) was used to investigate polymorphism among 43 Hirsutella thompsonii isolates (33 from Thailand) obtained from various mite species. The outgroups were an unidentified Hirsutella isolate along with Hirsutella nodulosa and Hirsutella kirchneri. Phylogenetic analyses of the AFLP data showed significant variation among isolates and the existence of three $H$. thompsonii clades. We also investigated the isolates using PCR with specific primers for the Hirsutella exotoxin gene Hirsutelin $A(H t A)$ and 18 of these isolates were used for sequencing of the partial $\beta$-tubulin gene. Phylogenetic analyses of $\beta$-tubulin sequences showed two distinct $H$. thompsonii clades, one of which included AFLP clades I and II. For both markers grouping of the $H$. thompsonii isolates was not related to either host mite species or geographical origin, although for the $H t A$ gene one clade contained only isolates with no detectable $H t A$ band. These results confirm the high intraspecific polymorphism of $H$. thompsonii, and maximum likelihood analysis showed no monophyletic group within this species. To refine the taxonomy of this genus other studies should be undertaken using additional molecular markers and several other Hirsutella isolates.
\end{abstract}

Key words: entomopathogenic fungus, mites, molecular markers.

Received: October 18, 2005; Accepted: February 14, 2006.

\section{Introduction}

The genus Hirsutella (Hypocreales) contains a variety of fungal pathogens isolated from numerous mite, nematode, and insect hosts (McCoy, 1996; Jaffee, 2000; Chandler et al., 2000; Van der Geest et al., 2000). For example, the Hirsutella species $H$. nodulosus, $H$. citriformis and $H$. gigantean, infect lepidopterans, hemipteran and dipterans producing structures composed of a compact group of erect conidiophores (synnemata) while H. rhossiliensis and $H$. minnesotensis infect plant-parasitic nematodes. The most wide-studied species from this genus is the mitespecific pathogen Hirsutella thompsonii (McCoy, 1981), a mononematous species that has been separated into three morphologically distinct groups consisting of the tropical variety synnematosa, the subtropical variety vinacea and the temperate variety thompsonii. This fungus has a worldwide distribution on different eriophyoid and tetranychid

Send correspondence to Myrian S. Tigano. Embrapa Recursos Genéticos e Biotecnologia, Parque Estação Biológica, Final Av. W/5 Norte, 02372, 70770-900 Brasília, DF, Brazil. E-mail: myrian@ cenargen.embrapa.br. mite hosts and during hot, humid weather can cause spectacular natural epizootics among mite populations (e.g. citrus rust mites, blueberry, coconut and tomato mites, etc.) and is considered to be a major natural enemy of various mite pests (Chandler et al., 2000).

Isolates of $H$. thompsonii have displayed phenotypic plasticity in vitro and certain isolates produce multiple conidial states (McCoy, 1996). Isoenzyme analyses of 15 geographically diverse $H$. thompsonii isolates has shown a high degree of intra-specific variability even among morphologically similar Hirsutella isolates (Boucias et al., 1982). Maimala et al. (2002) reported that the major hosts of $H$. thompsonii are eriophyoid mites displaying specific host plant preferences and that many $H$. thompsonii isolated from a range of eriophyiids varied in their ability to produce exotoxins such as Hirsutellin A (HtA). More recently, (Maimala, 2004) reported extensive plasticity in the growth characteristics of $H$. thompsonii isolated from a range of eriophyiids and one may speculate that the variation exhibited by $H$. thompsonii strains may have co-evolved with the specific mite-plant interactions. 
A major objective of the work described in this paper was to determine if the variation observed in $H$. thompsonii is linked to phenotypic plasticity or genotypic variation. Amplified fragment length polymorphism (AFLP) were used to examine $H$. thompsonii isolates exhibiting a spectrum of phenotypic differences and the results were complimented by an analysis of $H t A$ and $\beta$-tubulin gene data.

\section{Material and Methods}

\section{Fungal strains}

In this study we used 43 Hirsutella thompsonii Fisher isolates collected from various mite species, 33 isolates having been collected from various mite species inhabiting different plants in various regions of Thailand (Table 1, Maimala et al., 2002). The outgroups consisted of Hirsutella isolate 624 (unidentified to species level), Hirsutella nodulosa and Hirsutella kirchneri, from the United States Agricultural Research Service (USDA-ARS) Entomopathogenic Fungal Collection.

\section{DNA extraction}

Isolates were inoculated into $250 \mathrm{~mL}$ flasks containing $40 \mathrm{~mL}$ of malt extract broth (glucose, 1\%; malt extract $0.3 \%$; peptone $0.5 \%$; yeast extract, $0.3 \%$ ) and incubated at $25^{\circ} \mathrm{C}$ at 250 revs $\min ^{-1}$ for 4 days. Mycelial samples were collected on Whatman number 1 filter-paper using vacuum filtration, frozen at $-70{ }^{\circ} \mathrm{C}$, lyophilized and stored at $-20{ }^{\circ} \mathrm{C}$. About $25 \mathrm{mg}$ of the lyophilized mycelia of each sample were frozen in liquid nitrogen, crushed in a mortar and the total genomic DNA extracted using a modification of the cetyltrimethylammonium bromide (CTAB) DNA extraction protocol of Boucias et al. (2000a).

\section{AFLP analysis}

For each sample, 0.3-2.0 $\mu \mathrm{g}$ of genomic DNA was digested with EcoRI and ligated to EcoRI adaptors in a single overnight reaction at $37^{\circ} \mathrm{C}$ (Suazo and Hall, 1999). The digestion-ligation reactions were diluted with TE buffer to a final volume of $200 \mu \mathrm{L}$ and stored at $-20^{\circ} \mathrm{C}$. A series of six 19-mer primers (synthesized by Gemini Biotech Houston, TX) were used, consisting of the EcoRI adapter sequence GACTGCGTACCAATTC plus three 3' selective nucleotides (AGG, AGT, GGC, ACC, CGA and GGG). The amplification reactions were conducted in a volume of $25 \mu \mathrm{L}$ containing the anchor-annealed EcoRI fragments, primer and Taq DNA polymerase using the conditions established by Suazo and Hall (1999) and the PCR products separated by electrophoreses on $1.5 \%(\mathrm{w} / \mathrm{v})$ agarose-synergel $(0.7 \%$ $(\mathrm{w} / \mathrm{v})$ agarose and $0.4 \%(\mathrm{w} / \mathrm{v})$ synergel; Diversified Biotech, Boston, MA), stained with ethidium bromide and photographed under UV light.

\section{Analysis of the $\beta$-tubulin and Hirsutelin A genes}

Partial $\beta$-tubulin sequences were PCR amplified using primers designed from consensus regions of selected fungal, algal and protozoan $\beta$-tubulin genes, the primers being $\beta$ tubF 5' TGGGCYAARGGYCACTACACYGA 3' and $\beta$ tubR 5' TCAGTGAACTCCATCTCRTCCAT 3' (Tartar et al., 2002). PCR reactions were performed in a final volume of $25 \mu \mathrm{L}$ containing $1 \mu \mathrm{L}$ of genomic DNA, $0.4 \mu \mathrm{M}$ of primers, $200 \mu \mathrm{M}$ of dNTPs, 1x Taq recommended buffer, and 1 unit of Taq DNA polymerase (Fisher Scientific, Pittsburg, PA). The cycling program was 1 min at $94{ }^{\circ} \mathrm{C}$ and then 30 cycles ( 1 min denaturation at $94{ }^{\circ} \mathrm{C}$ followed by $1 \mathrm{~min}$ annealing at $55^{\circ} \mathrm{C}$ and $2 \mathrm{~min}$ extension at $68^{\circ} \mathrm{C}$ ) with a final 6 min elongation step at $68^{\circ} \mathrm{C}$. The PCR products were purified using a QIAquick PCR purification kit (QIAGEN Inc., Santa Clara, CA) and then sent to the Interdisciplinary Center for Biotechnology Research (ICBR) at the University of Florida for sequencing.

The $H t A$ gene was PCR amplified from the different DNA samples using the primers DGB35 (5'-CATATGAA AGCCTTTACTGCCATTCTC-3') and DGB14 (3'-ATCT CAGAACCAACGAGCCTAGG-5') (Maimala et al., 2002). The PCR conditions were the same as for the $\beta$-tubulin gene amplification, except that the annealing temperature used for these primers was $60{ }^{\circ} \mathrm{C}$. The PCR products were separated by electrophoreses on $1 \%(\mathrm{w} / \mathrm{v})$ agarose gel and visualized using ethidium bromide staining.

\section{Phylogenetic analyses}

Bands from AFLP analysis were scored as present or absent using digitized photographs of the gels. Experiments were repeated at least once, and only DNA fragments consistently present were recorded and considered to be binary characters. DNA fingerprints of each isolate were converted into a binary matrix. The data were assumed unordered with no a priori weighting.

The partial $\beta$-tubulin gene sequences were initially aligned with GenBank data retrieved using the Clustal X program version 1.83 (Thompson et al., 1997) and the alignments refined visually using the MacClade program version 4.02 (Sinauer Associates, Inc., Sunderland, MA, USA). Three homologous GenBank $\beta$-tubulin gene sequences from the fungi Neurospora crassa (M13630) Colletotrichum gloeosporioides f. sp. aeschynomene (U14138) and Cordyceps bassiana (AY366063) were included in the alignment. Gene genealogies were reconstructed using the distance-based, neighbor joining ( $\mathrm{NJ}$; Saitou and Nei, 1987), and the discrete character-based, maximum parsimony (MP) and maximum likelihood (ML), algorithms included in the PAUP* program version 4.0b10 (Swofford, 2002). Maximum parsimony analysis was performed using a heuristic search including 1,000 bootstrap replicates of random addition sequences and the 
Table 1 - Data on the Hirsutella isolates examined in this study. The HtA gene was detected using the PCR reaction (- no band; + weak band; ++,normal band) and the AFLP and $\beta$-tubulin clades (I, II, III and IV) were constructed by maximum parsimony tree analysis of AFLP and partial $\beta$-tubulin gene sequence data (NA $=$ not analyzed and an asterisk $(*)$ represents the isolates standed separated from the clades).

\begin{tabular}{|c|c|c|c|c|c|c|}
\hline $\begin{array}{l}\text { Hirsutella species and isolate } \\
\text { number }\end{array}$ & Host mite & Isolation location & $\begin{array}{l}\text { Year } \\
\text { isolated }\end{array}$ & $\begin{array}{l}H t A \\
\text { gene }\end{array}$ & $\begin{array}{l}\text { AFLP } \\
\text { clade }\end{array}$ & $\begin{array}{c}\beta \text {-tubulin } \\
\text { clade }\end{array}$ \\
\hline \multicolumn{7}{|l|}{ H. thompsonii isolates } \\
\hline 13 & Phyllocoptruta oleivorus & Yala, Thailand & 1991 & - & I & I \\
\hline $18 \mathrm{II}$ & P. oleivorus & Nan, Thailand & 1991 & + & $*$ & II \\
\hline 21 & P. oleivorus & Phrae, Thailand & 1991 & - & II & II \\
\hline 1707 & P. oleivorus & Chanthaburi, Thailand & 1999 & - & II & NA \\
\hline $\mathrm{H} 4$ & P. oleivorus & Pathumthani, Thailand & 1992 & - & II & NA \\
\hline HT72 & P. oleivorus & USA & 1972 & ++ & I & NA \\
\hline HTF74 & P. oleivorus & USA & 1974 & ++ & I & NA \\
\hline HTF75 & P. oleivorus & USA & 1975 & ++ & I & I \\
\hline HTF87 & P. oleivorus & USA & 1987 & ++ & I & NA \\
\hline HTFPB & P. oleivorus & USA & Unknown & ++ & I & NA \\
\hline HTDowAl & P. oleivorus & USA & Unknown & ++ & I & NA \\
\hline HTDowPh & P. oleivorus & USA & Unknown & ++ & I & NA \\
\hline JAB04 & P. oleivorus & Brazil & Unknown & ++ & I & NA \\
\hline $\mathrm{NC}$ & Acalitus vaccinii & USA & Unknown & ++ & I & NA \\
\hline 884 & Phyllocoptruta musae & Chai Nat, Thailand & 1998 & ++ & I & NA \\
\hline 887 & Phyllocoptruta malligai & Chai Nat, Thailand & 1998 & ++ & I & NA \\
\hline 1289 & P.malligai & Trat, Thailand & 1999 & ++ & II & NA \\
\hline 1962 & Phyllocoptruta sp. & Nakhon Pathom, Thailand & 2000 & ++ & II & NA \\
\hline 2089 & Phyllocoptruta sp. & Phitsanulok, Thailand & 2000 & ++ & I & NA \\
\hline 898 & Aculops caricae & Chai Nat, Thailand & 1998 & ++ & I & NA \\
\hline 966 & A. caricae & Chon Buri, Thailand & 1998 & ++ & I & NA \\
\hline 1730 & A. caricae & Chanthaburi, Thailand & 1999 & - & II & II \\
\hline 1764 & A. caricae & Chanthaburi, Thailand & 1999 & ++ & II & NA \\
\hline 885 & Aculops cratevi & Chai Nat, Thailand & 1998 & ++ & II & NA \\
\hline 2121 & Aculops grabrati & Phitsanulok, Thailand & 1900 & ++ & I & I \\
\hline 3B & Vilaia cythereae & Nonthaburi, Thailand & 1990 & ++ & II & NA \\
\hline 1840 & Vilaia pamithus & Chiang Mai, Thailand & 1999 & ++ & II & II \\
\hline 225 & Vilaia strebli & Nakhon Pathom, Thailand & 1996 & ++ & II & NA \\
\hline 1690 & V. strebli & Rayong, Thailand & 1999 & ++ & II & II \\
\hline 915 & V. strebli & Chai Nat, Thailand & 1998 & - & III & III \\
\hline 2077 & V. strebli & Uttrradit, Thailand & 2000 & - & III & III \\
\hline 968 & Vilaia morindae & Chon Buri, Thailand & 1998 & - & III & III \\
\hline 1722 & Vilaia thaianae & Chanthaburi, Thailand & 1999 & - & III & III \\
\hline 2057 & Vilaia sandorici & Phitsanulok, Thailand & 2000 & - & $*$ & III \\
\hline 2110 & V. sandorici & Phitsanulok, Thailand & 2000 & - & $*$ & III \\
\hline 873 & Vasates spondiasi & Chai Nat, Thailand & 1998 & ++ & I & I \\
\hline 1401 & V. spondiasi & Nakhon Pathom, Thailand & 1999 & ++ & I & NA \\
\hline 1614 & $V$. spondiasi & Chachoengsao, Thailand & 1999 & ++ & II & NA \\
\hline Pink & Aculus pelekassi & USA & Unknown & ++ & I & NA \\
\hline 2109 & Aculus menoni & Phitsanulok, Thailand & 2000 & - & II & II \\
\hline 1305 & Aculus sp. & Trat, Thailand & 1999 & ++ & II & NA \\
\hline 1813 & Aculus sp. & Chiang Mai, Thailand & 1999 & - & I & NA \\
\hline 1773 & Aculus sp. & Nakhon Pathom, Thailand & 1999 & - & III & III \\
\hline \multicolumn{7}{|l|}{ Outgroups } \\
\hline H. kirchneri ARSEF5550 & Lolium perenne & United Kingdom & 1981 & - & NA & IV \\
\hline H. nodulosa ARSEF5473 & Dioryctria zimmermani & USA & 1995 & - & NA & IV \\
\hline Hirsutella isolate 624 & Vilaia elaeocarpi & Chanthaburi, Thailand & 1997 & - & NA & IV \\
\hline
\end{tabular}


tree-bisection-reconnection branch swapping algorithm with the steepest descend option not in effect. The NJ tree was obtained using the mean-character difference for the AFLP dataset and the Log Determinant distance measure for the $\beta$-tubulin sequences, each using 1,000 bootstrap replicates. The ML analysis was applied only to the $\beta$-tubulin sequences dataset. The GTR $+\mathrm{G}$ model favored by ModelTest program version 3.06 (Posada and Crandall, 1998) was used for the ML searches which were conducted heuristically with 100 bootstrap replicates.

\section{Results}

The HtA gene PCR amplification with HtA genespecific primers confirmed the results previously obtained by Maimala et al. (2002). A consistent $\sim 600$ bp band (data not shown) was produced by $67 \%$ of the $H$. thompsonii isolates $(\mathrm{HtA}+), 17 \%$ of which produced weak bands (Table 1). The Hirsutella species other than H. thompsonii showed no detectable $H t A$ bands.

The AFLP analysis of the $43 \mathrm{H}$. thompsonii isolates and Hirsutella isolate 624 (Table 1) with the five different primers produced identical AFLP profiles for isolates HTF75 and HTF87 and also for isolates 1707 and H4, so in these cases only the profiles of isolates HTF75 and 1707 were used in the final analyses. The amplification of the anchor-ligated EcoRI fragments with all the primers used produced an array of scoreable bands with abundant polymorphisms that were resolved on ethidium bromide-stained agarose synergels (Figure 1). The number of polymorphic AFLP bands selected varied from 25 to 39 per primer and their sizes ranged from $\sim 250$ to $3,000 \mathrm{bp}$. A total of 183 fragments were scored as AFLP markers. No single fragment was found to be amplified in all of the 42 isolates analyzed (i.e., no fragment was monomorphic) and 161 were parsimony-informative characters. The topologies of the $\mathrm{NJ}$ and MP trees were identical, so only the parsimony tree is shown in Figure 2. Three clades (I, II and III) were identified, with the Hirsutella isolate 624 and three $H$. thompsonii isolates (18 II, 2057 and 2110) being outliers which remained independent from the clades. In both MP and NJ analyses clades I and III were well defined with bootstrap support (bs) of 86\%-100\%, while clade II was poorly supported and included two groups with bs of $79-84 \%$. Each of these groups contained subgroups that were supported by bootstrap values from NJ and MP analysis. Interestingly, the AFLP clades were not related to original host or geographical location (Table 1, Figure 2). For example, seven $H$. thompsonii isolates obtained from the mite Phyllocoptruta oleivorus were included among the nine isolates from the USA (Table 1) which all grouped in clade 1, while three isolates from the same host species were placed in clade II. Furthermore, the well-supported Clade III included isolates from different regions from Thailand and from various hosts (Table 1, Figure 2). In several instances, clade designation seemed to be correlated with the expression of the $H t A$ gene (Table 1). For example, all of the members in clade III did not produce the HtA PCR product $\left(\mathrm{HtA}^{-}\right)$whereas clade I contained mainly $\mathrm{HtA}^{+}$isolates (17 out of 19) while clade II contained a mix of $\mathrm{HtA}^{+}$ and $\mathrm{HtA}^{-}$isolates (Table 1, Figure 2).

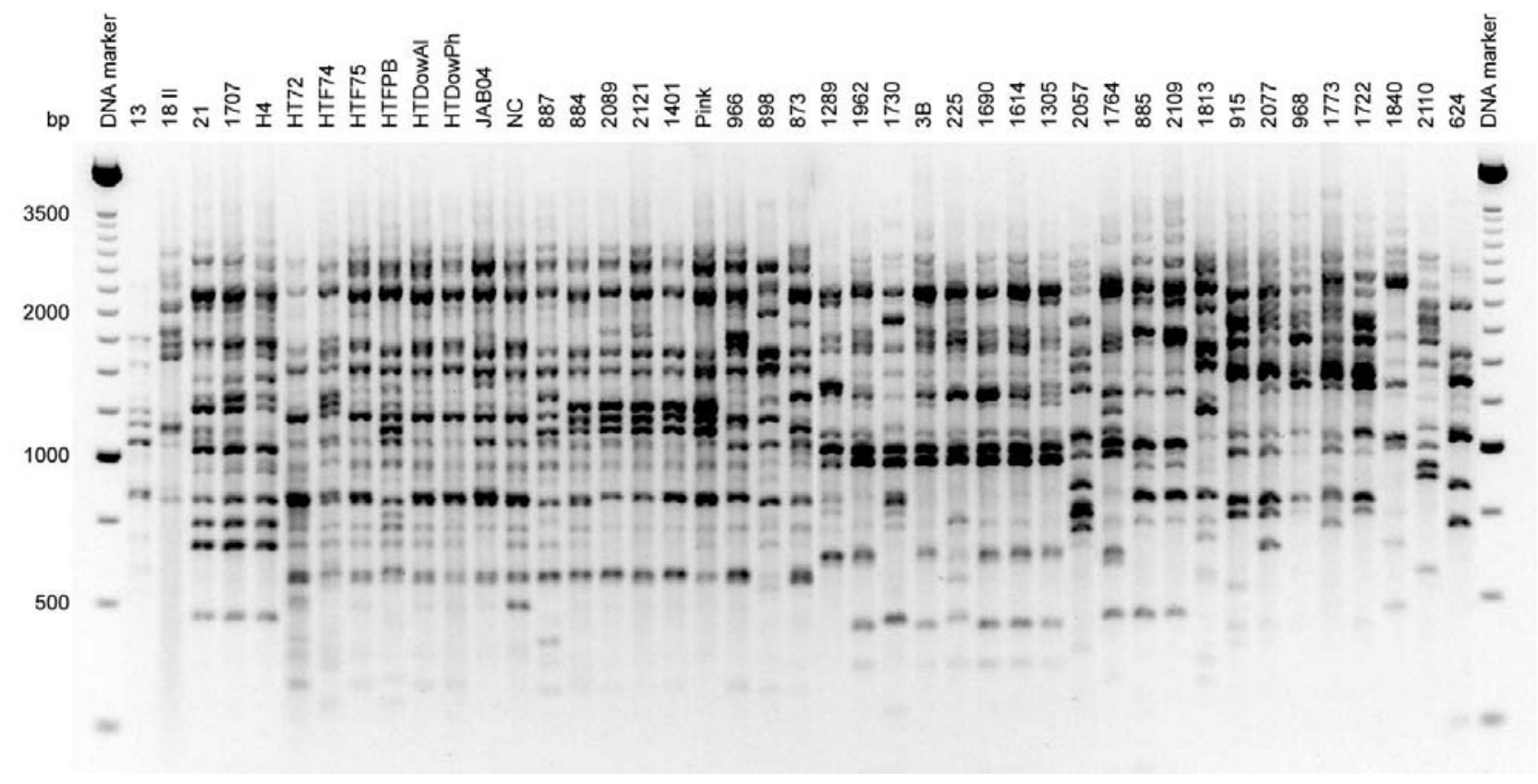

Figure 1 - Example of ethidium bromide-stained AFLP reaction products electrophoresed on 1.5\% agarose-synergel. The first and last lanes represent the 250 bp DNA Ladder (Invitrogen). 


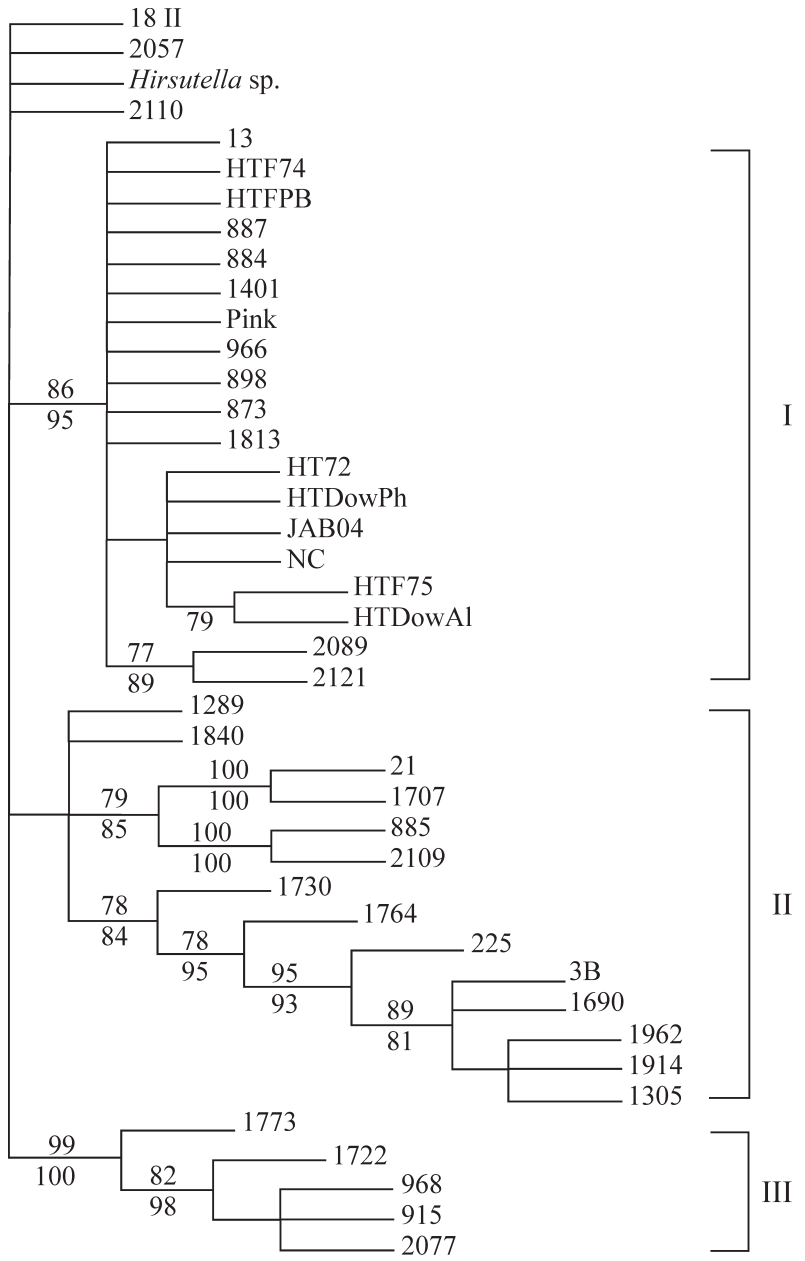

Figure 2 - Maximum parsimony (MP) tree based on AFLP characters. This tree also represents the topology obtained with the neighbor joining (NJ) analysis. Numbers next to the branches are bootstrap percentage values, based on 1,000 replicates and obtained with MP (above) and NJ (below) analyses. The outgroup is Hirsutella isolate 624 .

The $\beta$-tubulin sequences analyses showed that the $\beta$ tubF and $\beta$ tubR primers amplified a segment of the $\beta$ tubulin gene that includes 'intron F' from the Neurospora crassa $\beta$-tubulin gene sequence (GenBank M13630). The partial $\beta$-tubulin sequences obtained from the 20 Hirsutella isolates analyzed consisted of 750 (isolate 2109) to 805 (isolate 1730) bp. Identical sequences were obtained for isolates HTF75, 873 and 2121 so only the HTF75 sequence was included in subsequent analyses. The $57 \mathrm{bp}$ related to the intron was not included in the alignment of the sequences. The final alignment contained 681 positions, of which 186 were variable and 124 were parsimonyinformative characters. The sequences have been deposited in GenBank. Phylogenetic trees generated by both distance and parsimony methods had similar topologies, and are represented by the maximum parsimony tree (MP) shown in Figure 3 which shows four clades (I to IV). Some of the isolates that were in clade I and II in the trees obtained with the

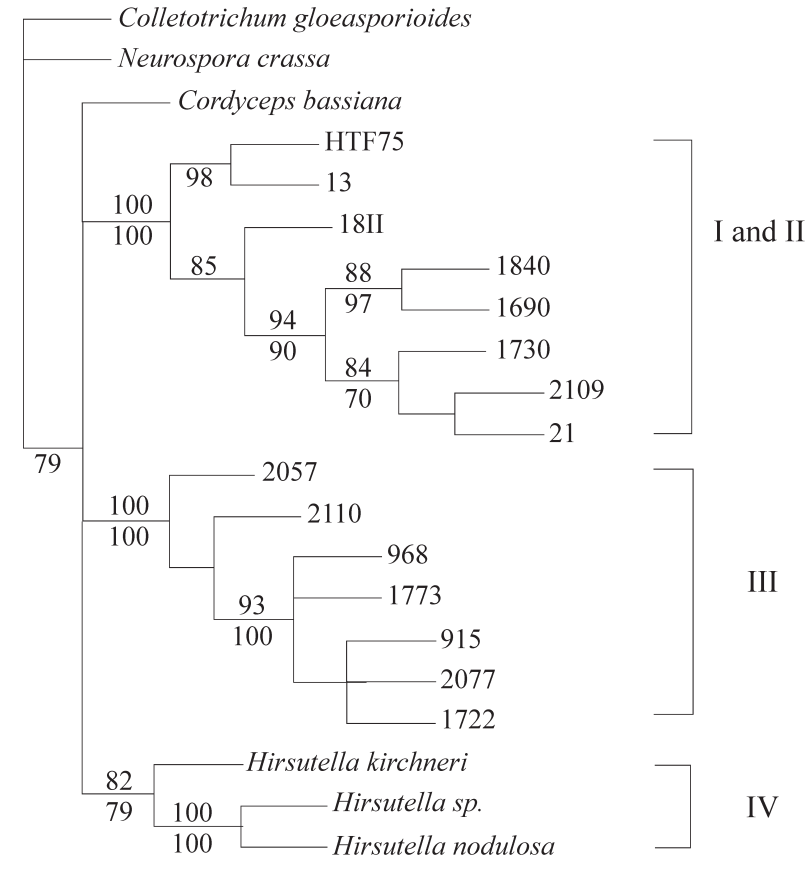

Figure 3 - Maximum parsimony (MP) tree based on $\beta$-tubulin sequences. This tree also represents the topology obtained with the neighbor joining (NJ) analysis. Numbers next to the branches are bootstrap percentage values, based on 1,000 replicates and obtained with MP (above) and NJ (below) analyses. The outgroups are Neurospora crassa and Colletotrichum gloeosporioide.

AFLP dataset were shown to be in a strongly supported group ( $100 \%$ bs for both NJ and MP analyses) that included the well-supported clade I ( $98 \%$ bs) and clade II ( $85 \%$ bs). The maximum likelihood tree (ML) showed a slightly different topology, showing also clades I and II as a unique clade, but a close relationship ( $77 \%$ bs) between clade III and clade IV (Figure 4).

\section{Discussion}

Our research showed that, in general, $H$. thompsonii isolates obtained from various mite species showed high polymorphism for the molecular markers studied. Amplified fragment length polymorphism (AFLP) has proved to be a powerful DNA marker technique to evaluate polymorphism among isolates of $H$. thompsonii as well for other fungi (Boucias et al., 2000a, b). Based on AFLP analyses, the different $H$. thompsonii were grouped into three clades uncorrelated with either location or mite species. Different strains isolated from the same mite species were often found in two or more of the delineated clades (Table 1). Similarly, no correlation was found between phenotypic data (Maimala et al., 2002; Maimala, 2004) and clade designation, with, for example, isolates 873 (clade I) and 1690 (clade II) showing both polyblastic conidia and synnemata whereas other isolates $(13,1614,1707,1722,1730,1764$ and 1813), distributed in all three clades, produce polyblastic conidia without synnemata (Maimala et al., 2002). Comparisons of other phenotypic data, such as plant host, 


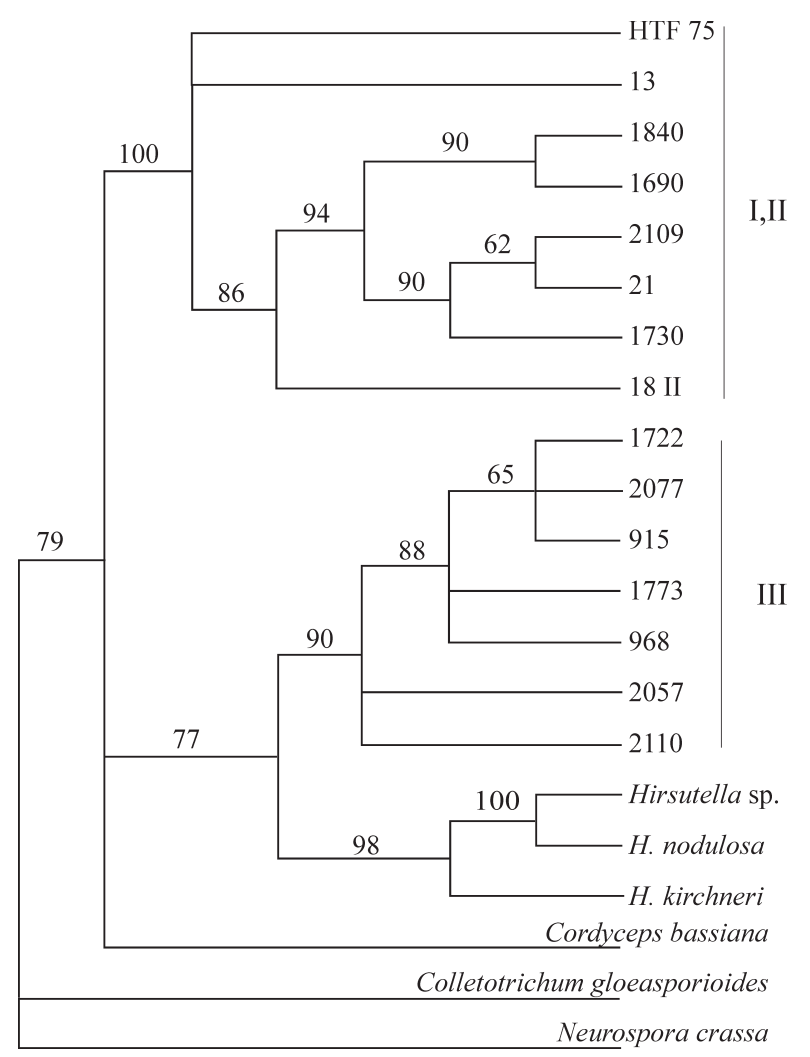

Figure 4 - Maximum likelihood tree based on $\beta$-tubulin sequences. Numbers next to the branches are bootstrap percentage values, based on 1,000 replicates. The outgroups are Neurospora crassa and Colletotrichum gloeosporioide.

fungal growth rate, colony color and morphology, and phialide size (Maimala, 2004) failed to correlate any morphological phenotype(s) to the genotypic data resulting from our AFLP analysis. However, clades I and III showed a relationship with the presence of the $H t A$ gene, with Clade I members (except for one isolate) being $\mathrm{HtA}+$ and all clade III members being HtA-.

Because of the high AFLP marker polymorphism observed among the $H$. thompsonii isolates studied, we conducted partial sequencing of the $\beta$-tubulin gene on a select group of isolates. Analyses of sequence data is a widely used approach in the study of species delimitation and the analysis of DNA sequence information within the $\beta$-tubulin region has provided robust phylogenetic information for fungi (Jong et al., 2001; ODonnell et al., 1998), including the entomopathogenic fungi of the genus Paecilomyces and Nomuraea (Han et al., 2002, Luangsa-Ard et al., 2005). Based on $\beta$-tubulin analysis, we have observed that Hirsutella grouped with a branch that included C. bassiana, suggesting that this genus possesses affinities to the Hypocreales. Stensrud et al. (2005) reported that Cordyceps species are commonly the teleomorphic stage of anamorph genera of many entomopathogenic fungi. The connection of Hirsutella and Cordyceps was first observed for the ant pathogen Cordyceps unilateralis whose anamorph is Hirsutella formiacarum (Petch, 1924) and several other Cordyceps species have been reported to be the teleomorphs of various Hirsutella species (Kendrick and Carmichael, 1973; Samson et al., 1988).

Our $\beta$-tubulin gene analysis allowed the detection of intraspecies variability. In both $\beta$-tubulin trees (MP and ML), clades I and II from AFLP data were placed in a unique well-supported clade, and clade III included two isolates which were in separate clades in the AFLP analyses. We also found that $\beta$-tubulin clade IV included Hirsutella isolate 624, H. nodulosa and H. kirchneri (the non-thompsonii isolates ), indicating that Hirsutella isolate 624 obtained in Thailand was closely related to the mite pathogen $H$. nodulosa.

The ML tree indicates that $H$. thompsonii is not monophyletic because clade III isolates were more closely related to $H$. nodulosa and $H$. kirchneri than to the rest of the $H$. thompsonii isolates studied. Clade III isolates were all $H t A^{-}$and were isolated from Thailand, albeit from different locations and hosts. The fact that $H$. thompsonii isolates are difficult to identify is due to the pleomorphic character of this fungus and the high polymorphism detected among different isolates in regard to several biological characteristics and molecular markers (Boucias et al., 1982, Mozes-Koch et al., 1995, Van der Geest et al., 2000). Our results have confirmed that the taxonomy of Hirsutella is complex (Samson et al., 1988) and that genomic characterization, through the analysis of other DNA sequences, should be developed in order to refine the taxonomy of $H$. thompsonii.

\section{Acknowledgments}

This research was supported in part by funds provided to M. Tigano by the Brazilian agencies Embrapa and Capes. The authors thank R. McTiernan and D. Purcell for technical support, R. Humber (USDA) for providing isolates and for a critical review of the manuscript and A. Jeyaprakash for a critical review of the manuscript.

\section{References}

Boucias D, Stokes C, Suazo A and Funderburk J (2000a) AFLP analysis of the entomopathogen Nomuraea rileyi. Mycologia 92:638-648.

Boucias D, Tigano MS, Sosa-Gomez DR, Glare TR and Inglis PW (2000b) Genotypic properties of the entomopathogenic fungus Nomuraea rileyi. Biological Control 19:124-138.

Boucias D, McCoy CW and Joslyn DJ (1982) Isozyme differentiation among 17 geographical isolates of Hirsutella thompsonii. Journal of Invertebrate Pathology 39:329-337.

Chandler D, Davidson G, Pell JK, Ball BV, Shaw K and Sunderland KD (2000) Fungal biocontrol of acari. Biocontrol Science and Technology 10:357-384.

Han Q, Inglis GD and Hausner G (2002) Phylogenetic relationships among strains of the entomopathogenic fungus, 
Nomuraea rileyi, as revealed by partial $\beta$-tubulin sequences and inter-simple sequence repeat (ISSR) analysis. Letters in Applied Microbiology 34:376-383.

Jaffe BA (2000) Augmentation of soil with the nematophagous fungi Hirsutella rhossiliensi and Arthrobotrys haptyla. Phytopathology 90:498-504.

Jong SN, Lévesque CA, Verkley GJM, Abeln ECA, Rahe JE and Braun PG (2001) Phylogenetic relationships among Neofabraea species causing tree cankers and bull's-eye rot of apple based on DNA sequencing of ITS nuclear rDNA, mitochondrial rDNA, and the $\beta$-tubulin gene. Mycological Research 105:658-669.

Kendrick WB and Carmichael JW (1973) Hyphomycetes. In: Ainsworth GC, Sparrow FK and Sussman AS (eds) The Fungi: An Advanced Treatise. Academic Press, New York, pp 323-509.

Luangsa-Ard JJ, Hywel-Jones NL, Manoch L and Samson RA (2005) On the relationship of Paecilomyces sect. Isarioidea species. Mycological Research 109:581-589.

Maimala S (2004) Screening strains of Hirsutella thompsonii (FISHER) for mass production by solid state fermentation technology. PhD Thesis, Kasetsart University, Bangkok.

Maimala S, Tartar A, Boucias D and Chandrapatya A (2002) Detection of the toxin Hirsutellin A from Hirsutella thompsonii. Journal of Invertebrate Pathology 80:112-126.

McCoy CW (1996) Pathogens of eriophyoid mites. In: Lindquist EE, Sabelis MW and Bruin J (eds) Eriophyoid Mites - Their Biology, Natural Enemies and Control. Elsevier Science B.V., Amsterdam, pp 481-490.

McCoy CW (1981) Fungi: Pest control by Hirsutella thompsonii. In: Burges HD (ed) Microbial Control of Insects, Mites and Plant Diseases. Academic Press, New York, pp 499- 512.

Mozes-Koch R, Edelbaum O, Liveneh O, Sztejnberg A, Uziel A, Gerson U and Sela I (1995) Identification of Hirsutella species, isolated within a species and heterokaryons by random amplified polymorphic DNA (RAPD). Z Pflanzenkrankh Pflanzensch 102:284-290.

O’Donnell K, Cigelnik E and Nirenberg HI (1998) Molecular systematics and phylogeography of the Gibberella fujikuroi species complex. Mycologia 90:465-493.

Petch T (1924) Studies in entomogenous fungi. IV. Some Ceylon Cordyceps. Transactions of the British Mycological Society 10:28-45.

Posada D and Crandall KA (1998) MODELTEST: Testing the model of DNA substitution. Bioinformatics 14:817-818.

Saitou N and Nei M (1987) The neighbor-joining method: A new method for reconstructing phylogenetic trees. Molecular Biology and Evolution 4:406-425.

Samson RA, Evans HC and Latgé JP (1988) Atlas of Entomopathogenic Fungi. Springer Verlag, Berlin, 187 pp.

Stensrud O, Hywel-Jones NL and Schumacher T (2005) Towards a phylogenetic classification of Cordyceps: ITS rDNA sequence data confirm divergent lineages and paraphyly. Mycological Research 109:41-56.

Suazo A and Hall HG (1999) Modification of the AFLP protocol applied to honey bee (Apis mellifera L.) DNA. Bio-Techniques 26:704-709.

Swofford DL (2002) PAUP*: Phylogenetic Analysis Using Parsimony (*And Other Methods). Sinauer Associates, Inc., Sunderland, $140 \mathrm{pp}$.

Tartar A, Boucias DG, Adams BJ and Becnel JJ (2002) Phylogenetic identifies the invertebrate pathogen Helicosporidium sp. as a green alga (Chlorophyta). International Journal of Systematic and Evolutionary Microbiology 52:273-279.

Thompson JD, Gibson TJ, Plewniak F, Jeanmougin F and Higgins DG (1997) The Clustal X windows interface: Flexible strategies for multiple sequence alignment aided by quality analysis tools. Nucleic Acids Research 24:4876-4882.

Van der Geest LPS, Elliot SL, Breeuwer JAJ and Beerling EAM (2000) Diseases of mites. Experimental and Applied Acarology 24:497-560.

Associate Editor: Sérgio Olavo Pinto da Costa 